\title{
Toronto Health Libraries Association
}

THLA continues to provide local health librarians from a variety of workplaces with opportunities for learning, sharing, and socializing. As the new year begins, we are fortunate to be able to reflect on the events and accomplishments of 2010-2011.

\section{Events}

It was a busy year. Last November, THLA jointly cosponsored the MLA educational webcast ABCs of e-books: Strategies for the Medical Library with the Health Science Information Consortium of Toronto. It was well attended and very informative, both providing helpful overview information and practical suggestions that were very welcome for smaller libraries embarking on e-book collections. Our holiday social in November was enjoyed by all with an abundance of prizes provided by our supporters and donors, including Ovid. In March, our members were kept informed about the progress of the Canadian Virtual Health Library through a webinar hosted by Orvie Dingwall and Jennifer Bayne. In April, the Health Sciences Library at St. Michael's Hospital arranged a tour of its library and new home, the $\mathrm{Li} \mathrm{Ka}$ Shing International Healthcare Centre. It is an impressive, state of the art centre; and it was encouraging to find the library prominently and strategically positioned within the centre. Finally, the year's activities ended with the AGM on May 5th, hosted by the Hospital Library and Archives at The Hospital for Sick Children. The guest speaker was Dr. Susan Tallett, Chief of Education, who spoke about the Learning Institute and teaching and learning at Sick Kids.

\section{THLA annual prize in Health Sciences Librarianship - Allison McArthur}

Our annual prize was awarded at the University of Toronto iSchool Graduation Reception last June. Recipient Allison McArthur completed with distinction both the Health Sciences Information Resources course and Selected Topics in Health Informatics. Allison is an Information Specialist for the Public Health Planning and Implementation Branch of the Public Health Division at the Ministry of Health and Long-Term Care who successfully juggled work and study; and we celebrate her accomplishments. The award consists of free membership to THLA until December 2012 and a monetary prize. It is important that we foster librarianship in heath sciences, celebrate the accomplishments of graduates, and stay connected with the Faculty of Information at the University of Toronto.

\section{Executive news}

I am pleased to take on the responsibility of President after jumping into the President-Elect position midstream. I am a Library Coordinator at the Centre for Addiction and Mental Health (CAMH) Library where my work focuses on reference and research services. My career at CAMH began over 20 years ago when I entered the profession in mid life to return to my health science roots. One of the highlights of my career has been my involvement in Substance Abuse Librarians and Information Professionals (SALIS), an international organization representing libraries and resource centres that serve researchers, policy makers, practitioners, students, and the general public, much like CHLA. I have served as Chair and on many committees. Currently I am a member of the SALIS Advocacy Committee.

I am very fortunate to have the excellent support of Past President Corrina Switzer whose leadership has kept THLA vibrant. We also have the long-term experience of Penka Stoyanova (Treasurer) and Graziela Alexandrova, a former THLA President (Secretary). We thank our Past President Esther Atkinson for her years of dedicated service. Esther is now engaged in further graduate studies and we wish her well. We had a send-off dinner for Newsletter Editor Goldie Louie who moved to the United States. We will miss her technical skills and enthusiasm. This past year, we welcomed webmaster Susan Cheng from The Scarborough Hospital. Unfortunately, we begin our new year without a President-Elect or Newsletter Editor, so filling these positions is a priority.

Plans for 2011-2012 are in the works. We are fortunate to have maintained our membership numbers, but these are challenging times and we are all affected, directly or indirectly, by local and global trends in library closures and downsizing. Our goal in our THLA programming is to offer variety and flexibility with cost-effective, creative alternatives, as budgets and available time for educational events are shrinking. Staying connected and supporting each other is essential!

\section{Sheila Lacroix}

THLA President Centre for Addiction and Mental Health (CAMH) Library 33 Russell Street

Toronto, ON M5S 2S1, Canada

E-mail:president@thla.ca and sheila_lacroix@camh.net

THLA: http://www. thla.ca 